\title{
A PIACI INFORMÁCIÓK SZEREPE A VEZETŐI DÖNTÉSHOZATALBAN ÉS A TUDÁSTEREMTÉSBEN
}

A szerzố tanulmányában arra a kérdésre keresi a választ, milyen értéklánc mentén alakul át a piackutatásból származó információ marketingtudássá; mitốl függ, hogy a kutatási tanulmány csak egy újabb „papírkupac”, vagy a vezetói döntéstámogatás hasznos eszköze lesz. Eredményei szerint a piackutatások akkor épülnek be hatékonyan a marketing információs rendszerbe, ha a marketingvezetố bízik a piackutatóban, és jó minőségúnek tartja az elkészült piackutatást. A döntéshozók nagyobb valószínúséggel tanulnak azokból a piackutatásokból, amelyek egy konkrét kérdés, probléma megoldását segítik, mint az általánosabb, piacleíró tanulmányokból. A szerzó többváltozós matematikai-statisztikai modell felállításával azonosítja azokat a változókat, amelyek leginkább magyarázzák piackutatások eltérô mértékú felhasználását. A modellt egy 2003-ban végzett, hazai nagyvállalatokat reprezentáló kérdóíves felmérés mintáján empirikusan teszteli.

Kulcsszavak: piackutatás, marketing, vezetôi döntések

2005-ben nemzetközi szinten a vállalatok 19 milliárd dollárt költöttek piackutatásokra. A tíz új EU-tagországban a piackutatási piac a 2,7 százalékos átlagnál sokkal dinamikusabban, 12 százalékkal bóvült (www. esomar.org).

A piaci információk megszerzésére költött dollármilliárdok ellenére sem túnnek ,jobban értesültnek” a vállalatvezetók: Menon és Varadarajan (1992) szerint a menedzserek alig támaszkodnak a rendelkezésükre álló piaci információkra. Nemcsak azért fontos, hogy a vezetốk döntéseik során használják a rendelkezésükre álló információkat, az adatokból tanuljanak, szélesebb összefüggéseket ismerjenek fel, mert ezek megszerzése jelentôs anyagi terheket ró a vállalatokra, hanem a versenyképesség szempontjából is lényeges. Zaltman és Deshpandé (2000) szerint a versenytársak hasonló adatokhoz, információkhoz férnek hozzá; így ezek értelmezése, kontextusba helyezése, felhasználási képessége egyre inkább a piaci verseny kulcselemévé válik.

Kutatásunk tanulsága szerint a piackutató és a marketingvezető közötti bizalmi viszony a piackutatások hasznosulásának fó mozgatórugója; az elkészült tanulmánytól a piaci tudásig vezetố értéklánc elsô eleme. Miközben a bizalmi viszony közvetlenül nincs hatással arra, hogy a piackutatás a fiók mélyén „végzi-e”, vagy fontos döntések meghozatalát támogatja, közvetetten mégis a legfontosabb tényező. A marketingvezető piackutatóba vetett bizalma határozza ugyanis meg eredményeink szerint azt, hogy mennyire tartja jó minôségúnek a marketingvezetố az elkészült beszámolót.

Az intuícióknak ellentmondó módon a piackutató iránt érzett vezetối bizalom megléte vagy hiánya fontosabb szerepet kap a tanulmány minőségének észlelése során, mint maga a kutatás sajátosságai - ezek közül mi az eredmények várakozásokhoz történő illeszkedését, illetve az eredmények vállalatpolitikai erôterén belül történố elfogadhatóságát vizsgáltuk.

Miközben nagyvállalataink marketingszakemberei saját bevallásuk szerint az elkészült piackutatások túlnyomó többségét (55-67 százalékát) felhasználják a döntéshozatal során, addig a piackutatások kisebb része, $\mathrm{kb}$. harmada befolyásolja csak jelentôsen a meghozott döntéseket. Az adatokból arra következtethetünk, hogy a piackutatások fontos szerepet játszanak a döntések megerósítésében, de ritkán vezetnek drámaian új utak felfedezéséhez. Becsléseink szerint a tanulmányok kb. tíz százalékát nem használják a marketingszakemberek a döntéshozatal során. A marketingvezetốk túlnyomó többsége elméletileg vallja, hogy a piackutatásokból lehetne tanulni is, a ténymeg- 
állapítások továbbgondolása piacismerethez segíthet; azonban a megkérdezettek kevesebb mint egynegyede látja úgy, hogy a legutóbbi piackutatás segítségével új lehetôségek tárultak fel, vagy változott a piac természetéról alkotott képük.

Annak ellenére, hogy a piackutatási piac volumenét tekintve valószínúleg túl van az intenzív növekedés fázisán, kevesebb rendszerezett, akadémiai igényú, specifikusan a magyar piacról származó ismeret áll rendelkezésünkre arról, hogyan épülnek be a kutatások a marketingmenedzsment munkába, „mitôl függ”, hogy egy döntéshozó támaszkodik-e munkájában a piackutatásra, hogyan lehet jellemezni a „piackutatás-intenzív” vállalatokat. Tanulmányunkkal - amely elsóként nemcsak a piackutatások döntéshozatalban, de a piaci tanulásban betöltött szerepét is vizsgálja egy modellen belül - hozzá szeretnénk járulni a jelenség megértéséhez.

\section{A kutatási téma szakirodalmi háttere}

Tanulmányunkban egyaránt építünk a témakör magyarországi és külföldi kutatásaira.

Cikkünk első részében áttekintjük, hogy a hazai vállalatok milyen mértékben támaszkodnak piackutatási szolgáltatásokra a fogyasztók és versenytársak megismerése során. Jellemezzük, körülírjuk a piackutatás-intenzív vállalati kört. Itt elsôsorban magyarországi tanulmányok eredményeire támaszkodunk.

A kutatás második elemző-feltáró részében azokat a tényezőket azonosítjuk, amelyek leginkább meghatározzák, hogy egy elkészült piackutatás beépül-e a marketing információs rendszerbe, a menedzserek támaszkodnak-e az elkészült tanulmányra munkájuk során. Ebben a részben elsősorban vezetố amerikai marketing- és menedzsmentfolyóiratokban megjelent szakirodalmi referenciákra támaszkodunk.

A témakör elméleti megalapozása során - a kérdéskör sokrétűségének megfelelóen - több diskurzusra is támaszkodtunk. A marketing területén egy jól körülhatárolható kutatási irányzat vizsgálja a piaci információk felhasználásának kérdéskörét. Az irányzat képviselői elsősorban a piackutatások és piaci értesülések felhasználását vizsgálják. Ahogyan az az 1. ábrán is látható, az 1990-es évek közepén hangsúlyeltolódás figyelhető meg. Részben a tudásmenedzsment témakörének elméleti és gyakorlati felértékelődésével összefüggóen egyre gyakoribbakká válnak a marketing területén is az olyan empirikus kutatások, amelyek nem a kézzelfogható, „papíralapú” piackutatások, hanem a sokszor informális úton terjedô, vállalati munkatársak között megosztott piaci értesülések, pletykák szerepét vizsgálja a marketingmenedzsment munkában.

Jelen tanulmányunkban mégis a piackutatások felhasználásának témakörével foglalkozunk. Jóllehet számos korábbi amerikai tanulmány vizsgálta mitől függ, hogy a piackutatásokat felhasználják-e a menedzserek, ezek a tanulmányok fontos kérdésekre nem adtak választ. Talán a legfontosabb nyitott kérdés az, hogy mitól függ, tanulnak-e a menedzserek a piackutatásokból. Nyilvánvaló, hogy a piackutatások nemcsak mint döntéstámogató eszközök épülnek be a marketing információs rendszerbe. A kutatási tanulmányok sokszor szolgálnak a belsô és külső PR eszközeként (Keszey, 2003) - pl. a vállalati teljesítmény demonstrálása az anyavállalat felé, vagy egy előre meghozott döntés utólagos legitimizálása. A piackutatások sokrétú felhasználása miatt tanulmányunkban egy modell keretein belül vizsgáljuk a marketingmenedzsment szempontjából legfontosabb a döntéshozatalhoz és piaci tanuláshoz kötôdô hasznosulási módokat - ezzel meghaladva a témakör korábbi kutatásait.

1. ábra

Az empirikus kutatásokban

vizsgált információk körének változása

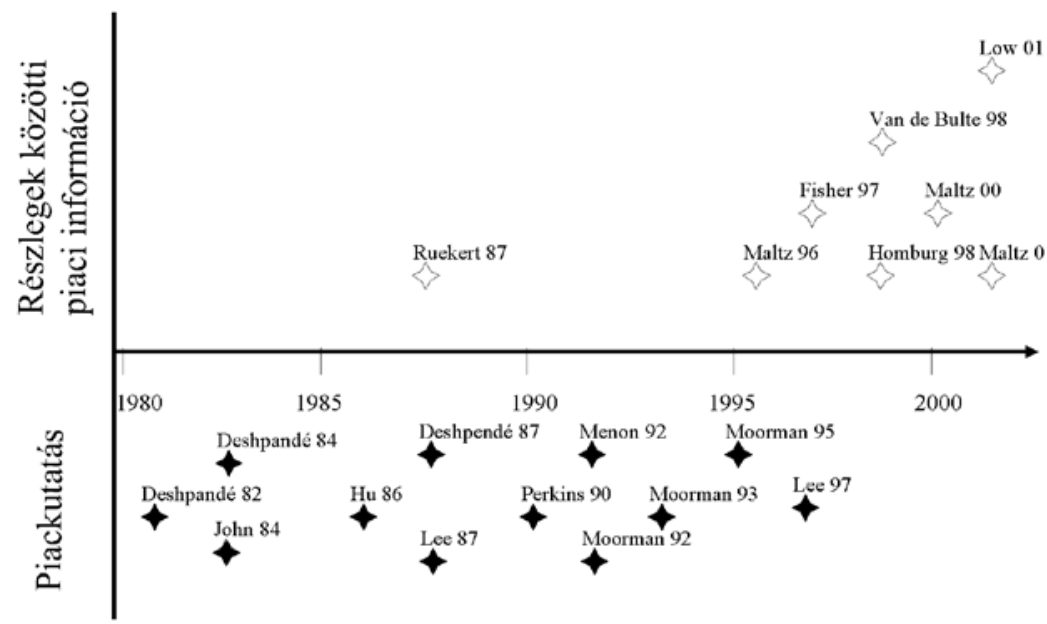

Tanulmányunkban támaszkodunk a piacorientációs iskola (pl. Kohli - Jaworski, 1990; Narver - Slater, 1990; Jaworski - Kohli, 1993; Hart - Diamantopoulos, 1993; Slater - Narver, 1995; Hooley - Cox et al., 2000) eredményeire is. A piacorientáció három pilléren, a piaci megfigyelések, információk gyújtésén (market intelligence generation), a szervezeten belüli megosztásán (intelligence dissemination) és az információkra történó válaszadáson (organisation-wide responsiveness) nyugszik. A piaci információ felhasználásának kérdésköre a harmadik területhez köthetô, 
mivel az információkra történő válaszadás és a piaci információ felhasználásának képessége szorosan öszszefügg - vagyis a piaci információk szervezeten belüli hasznosulásának megértése közelebb visz a piacorientáció jelenségének feltérképezéséhez is.

Kutatási hipotéziseink megfogalmazá-sa során segítségünkre voltak a marketing-innovációs diskurzus kutatási eredményei is. A marketinginnováció, a ,piacképes" új termékek előállítása szempontjából lényeges, hogy a marketingvezetốk hogyan képesek nem üzleti háttérrel rendelkezô kollégáikkal együttmúködni. Az irányzat kutatói (pl. Griffin - Hauser, 1992; Moorman, 1995; Moenaert - Souder, 1996; Van den Bulte Moenaert, 1998; Rindfleisch - Moorman, 2001) vizsgálták a marketingvezetốk gyártási és múszaki szakemberekkel történő együttmúködését a $\mathrm{K}+\mathrm{F}$ tevékenység során. Ezek a kutatási eredmények elsósorban azért érdekesek, mert az innovációs folyamatokhoz hasonlóan a piackutatási projekt során is olyan szakemberekkel dolgoznak együtt a marketingmenedzserek, akik elsôsorban nem üzletemberként, hanem elméleti kutatóként azonosítják magukat.

A piaci információk vezetối hasznosulását vizsgáló marketingdiskurzus nyilvánvalóan túlmutat a marketing diszciplínáján. Galbraith (1973); Tushman Nadler (1978); Daft - Lengel (1986); Dalebout (1993); Nonaka - Takeuchi (1995); Earl -Edwards et al. (1997); Osterloh - Frey (2000) - akik a menedzsmenttudományok különböző területeit (információmenedzsment, tudásmenedzsment, szervezetelméletek) képviselik - egyaránt vizsgálták az információ hasznosulását, és annak a tudáshoz füződő kapcsolatrendszerét.

\section{A piackutatás-intenzív vállalati kör}

Miközben a piackutatás mint tantárgy valamennyi „,business school” oktatási palettáján szerepel, kevesebbet tudunk arról, hogy a gyakorlatban a vállalatok milyen mértékben támaszkodnak erre az eszközre a környezet megismerése során. Kutatásunkban, egy 2001-ben, az OTKA támogatásával ${ }^{1}$ készített adatbázis felhasználásával ezért megvizsgáltuk, hogy Magyarországon a vállalatok általában milyen gyakran készíttetnek piackutatásokat. Az adatbázis, melyet 572 vállalatvezetố töltött ki, reprezentálja ${ }^{2}$ a 20 főnél több alkalmazottat foglalkoztató vállalatok körét.

Eredményeink szerint vállalataink fele egyáltalán nem készíttet piackutatásokat, és a cégek közel egyharmada ritkán vesz igénybe ilyen szolgáltatásokat. (2. ábra) Azonosítani lehet ugyanakkor egy olyan szúkebb csoportot - ide a vállalatok 15 százaléka tartozik -, amelyek fontosnak tartják a piackutatást a környe-

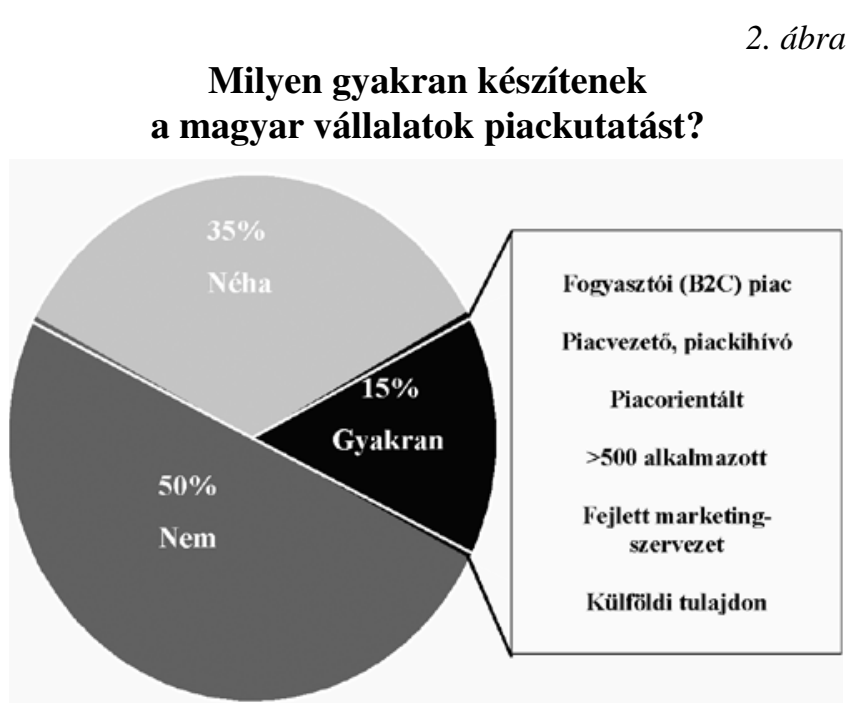

zet megismerésében. Górcsố alá véve ezt a szegmenst, megállapíthatjuk, hogy a piackutatás-intenzív körbe jellemzően a fogyasztói piacon tevékenykedô cégek tartoznak. Felülreprezentáltak azok a cégek, amelyek fogyasztói szolgáltatások elóállításával foglalkoznak, illetve a fogyasztási tömegcikkek és a tartós fogyasztási cikkek piacán tevékenykednek. Az országos átlagnál nagyobb számban fordulnak elố ebben a vállalati körben a távközlés, hírközlés és nagykereskedelem szereplôii. Eredményeinket támasztja alá Törốcsik (1996) is, aki az ipari piacokon tevékenykedô vállalatok vizsgálata kapcsán állapítja meg, hogy ,.... termelóeszközök marketingkutatásának alkalmazása relatív és abszolút értelemben is jóval alatta marad a fogyasztási cikkek területén végzett kutatásoknak. Úgy hoznak termelővállalataink közép- és hosszú távú döntéseket, hogy eszükbe sem jut a kutatástól remélni a megalapozást". Azok a vállalatok, amelyek az ipari, szervezeti piacokon vannak jelen, kevesebb számú vevővel vannak közvetlenebb, személyes kapcsolatban, mint a fogyasztói piac játékosai. Érthetô, hogy itt a kapcsolati hálókon keresztül szerzett értesülések fontosabbak lehetnek, mint a piackutatási információk. Eredményeink szerint a piackutatás-intenzív vállalati körbe jellemzően a piacvezetô, vagy kihívó (második vagy harmadik a piacon) pozícióban lévő vállalatok tartoznak. Érdekes eredmény, hogy a monopolhelyzetben lévố vállalatok a piackutatásnak a magyarországi átlagnál kisebb jelentőséget tulajdonítanak, és nem tartoznak a piackutatás-intenzív vállalatok közé. A szegmensre jellemző a piacorientált szemlélet. A piacorientált vállalatok törekednek vevőik véleményének megismerésére az igények kiszolgálására, illetve fontosnak tartják a fogyasztói elvárások formálását is (Bauer - Berács, 1998) - ennek nyilvánvalóan fontos eszköze lehet a piackuta- 
tás. A piackutatás-intenzív csoportban felülreprezentáltak a külföldi tulajdonú, ötszáz főnél több alkalmazottat foglalkoztató vállalatok. A piackutatást az átlagnál fontosabbnak tartják azok a vállalatok, amelyek fejlett marketingszervezettel rendelkeznek: a marketingfunkció képviselete megjelenik az igazgatótanácsban; és a marketingmunkát termék, illetve márkamenedzseri rendszerben építették fel.

\section{A piackutatástól a piaci tudásig vezetô értéklánc}

sége. A modell harmadik és negyedik eleme a piackutatás problémamegoldáshoz, döntéshozatalhoz kapcsolódó felhasználása, valamint a piaci tanulás, a kutatásból történő absztrakt következtetések levonása.

A modellben e négy tényezôt meghatározó elemeket (amelyeket a 3. ábrán látható modellünk bal oldalán, a független változók között láthatunk), valamint ezek egymáshoz füződő viszonyát vizsgáljuk. Ezt a modellünket egy 2003-ban, az OTKA támogatásával készült nagyvállalati adatbázison teszteltük (ld. részletesebben: a kutatás módszertana) (3. ábra).

3. ábra
Tanulmányunkban arra is keressük a választ, hogy mely tényezók járulnak leginkább az elkészült piackutatások felhasználásához. A szakirodalom áttekintése és marketingvezetókkel, felsôvezetókkel, valamint piackutatókkal folytatott mélyinterjúk ráirányították figyelmünket arra, hogy a piackutatások felhasználásában két tényezőnek kiemelt szerepe van. Az egyik a marketingvezető és piackutató között kialakult bizalom mértéke, a másik az elkészült piackutatás minóségének megítélése. A mélyinterjúk során alanyaink megerôsítették, hogy ez a két tényezô lényeges mozgatórugója a piackutatókkal történô együttmúködésnek.

\footnotetext{
„Annyira a bizalom a bázisa a piackutatásnak. Alapvető, hogy csak olyan kutatókkal dolgozunk, akikben száz százalékig megbízunk.” (Kozmetikai cikkek FMCG, marketingigazgató)
}

Fontos tehát, hogy megértsük mit is jelent egy marketingvezetô számára a ,jó minôségư” piackutatás, illetve milyen peremfeltételektôl függ, hogy a kutató megfelelő minőségú tanulmányokat legyen képes készíteni. Hasonlóan a bizalom dinamikáját, a bizalomra ható tényezóket is érdemes górcsố alá vennünk.

A piackutatástól a piaci tudásig vezetô értékláncmodellünk szerint négy fô elemból áll, ezek a kutatási modellünket bemutató 3. ábra középsô és jobb oldalán közvetítő és függő változóként jelennek meg. Az első elem, amely meghatározza a piackutatások hasznosulását a piackutató és a marketingvezető között fennálló bizalmi viszony; a második a piackutatás észlelt minő-

\section{Az értéklánc elsố eleme: a marketing-döntéshozó és a piackutató közötti bizalmi viszony}

\section{Mennyire bíznak a marketingvezetók a piackutatókban?}

Moorman - Zaltman et al. (1992) megközelítése alapján fogalmaztuk meg állításainkat a marketingvezető $p i$ ackutatóba vetett bizalmának mérése során. Rákérdeztünk, hogyan látja a marketing-döntéshozó a piackutató szakmai felkészültségét, mennyire tartja megbízhatónak, felelősségteljesnek és segítókésznek. Felmérésünk alapstatisztikáit az 1. táblázatban foglaltuk össze.

Felmérésünkból kitúnik, hogy a bizalom kérdése nem okoz általában problémát a két fél együttmúködésében. Az 1. táblázatban látható első két állítás a szakmai bizalommal, a kutatási kérdés „,személyre szabott” 
Mennyire bíznak a marketingvezetốk a piackutatókban? - alapstatisztikák

\begin{tabular}{|c|c|c|c|}
\hline \multicolumn{4}{|c|}{$\begin{array}{l}\text { A piackutatóba vetett bizalom } \\
\text { (Moorman - Zaltman et al., 1992) és (Moorman - Deshpandé et al., 1993) bizalommal összefüggó skálái alapján } \\
5 \text { fokozatú Likert-típusú skála } \\
\text { 1: egyáltalán nem jellemzó, 2: nem jellemzó, 3: jellemzó is meg nem is, 4: jellemzó, 5: teljes mértékben jellemzó }\end{array}$} \\
\hline A konstrukció mérését szolgáló állítás & Elemszám & Átlag & Szórás \\
\hline A kutató tapasztalatból választ adott azokra a kérdésekre is, amelyeket a kutatás hozott felszínre & 141 & 3,04 & 1,25 \\
\hline A kutató kreatív volt, munkájában sok volt az egyéni hozzáadott érték & 141 & 3,05 & 1,22 \\
\hline Meggyőződtem arról, hogy a kutató jól érti vállalatunk múködését & 141 & 3,52 & 1,19 \\
\hline A kutató még az utolsó pillanatban megfogalmazott igényeimet is figyelembe vette & 141 & 3,46 & 1,38 \\
\hline A kutatóval felmerült esetleges nézeteltéréseket közösen oldottuk meg & 141 & 3,51 & 1,48 \\
\hline $\begin{array}{l}\text { Biztos lehettem abban, hogy a kutatóval megosztott információkról a versenytársaink nem szereznek } \\
\text { tudomást }\end{array}$ & 142 & 3,65 & 1,52 \\
\hline A kutató pontosan betartotta a határidóket, a megbeszélésekre idóben érkezett & 142 & 3,96 & 1,21 \\
\hline
\end{tabular}

megválaszolási képességével kapcsolatos. Itt kissé alacsonyabb átlagokat kaptunk, mint a többi állításánál. Ez arra utal, hogy a korrekt szakmai munka mellett az igazi hozzáadott értéket adó, tanácsadás irányába mutató piackutatói szolgáltatás még nem terjedt el teljeskörúen, jóllehet a keresleti oldalon meglenne erre az igény. Eredményeink szerint a piackutatók szakmai felkészültsége mellett ügyfélismerettel is rendelkeznek, vagyis jellemzóen átlátják a megrendelói oldal igényeit, belsố viszonyait. A kutató hozzáállásával (az információk bizalmas kezelése, pontosság, határidôk betartása, együttmúködés) kapcsolatos állításoknál magasabb átlagértékeket kaptunk. A legmagasabb átlagot a határidő́k és idôpontok betartására vonatkozó kérdésünkre kaptuk. A piackutatóval megosztott információk bizalmas kezelése nyilvánvalóan fontos eleme a két fél közötti együttmúködésnek. Ezzel kapcsolatos kérdésünk eredménye azt mutatja, hogy jóllehet általában az információk bizalmas kezelésében nem kételkedik a megbízó, mégis elgondolkodtató, hogy itt tapasztaltuk a legmagasabb szórást, a legheterogénebb képet. Ez azt jelenti, hogy az etikus piackutatói magatartás követése mellett lényeges ezt az üzenetet hangsúlyozni és az ügyfélben tudatosítani is.

\section{A bizalmi viszonyt meghatározó tényezók}

Regresszióelemzéssel vizsgáltuk, hogy mely tényezók határozzák meg, mennyire bízik a piackutatóban a marketingvezetố - ennek eredményeit a 2. táblázatban láthatjuk (2. táblázat).

Eredményeink szerint a piackutatóba vetett bizalom kialakulására legnagyobb hatással a piackutató és a marketingvezetố együttmúködése van (ld.: 2. táblá- zat, EGYÜTTMÜK nevú faktor regressziós együttható értéke). Minél közvetlenebb és szorosabb az együttmúködés a felek között a kutatási probléma megfogalmazása, a kutatás megtervezése, az adatok elemzése, a következtetések/javaslatok megfogalmazása, megtárgyalása során, annál jobban fog bízni a marketingvezetô a piackutatóban.

A két fél közötti bizalom kialakulásában fontos szerepe van annak, hogy a felek ,egy nyelvet” beszéljenek. Deshpandé és Zaltman $(1982,1984)$ szerint a kommunikációt nehezíti, hogy a piackutatók elsôsorban kutatóként, elméleti szakemberként, míg a vezetôk üzletemberként tekintenek magukra. Az eltérô önazonossággal rendelkezô felek együttmúködési nehézségeit Caplan - Morisson et al. (1975) írták le, a jelenséget „two communities metaphor”, vagyis két

\section{2. táblázat}

\section{A bizalmi viszonyt meghatározó tényezók - a regresszióelemzés eredményei}

\begin{tabular}{|l|c|}
\hline Független változók & Regressziós együittható (t-érték) \\
\hline MEGLEP &,$- 158^{*}(2,033)$ \\
\hline EGYÜTTMÜK &, $469 * * *(6,222)$ \\
\hline MINŐSÉG &, $204 * *(2,674)$ \\
\hline F érték & $36,704 * * *$ \\
\hline R négyzet ${ }^{3}$ &, 464 \\
\hline
\end{tabular}

Szignifikancia szintek: ${ }^{*} \mathrm{p}<, 05 ; \quad * * \mathrm{p}<, 01 ; \quad * * * \mathrm{p}<0,001$

Jelmagyarázat:

MEGLEP: A piackutatás eredményeinek meglepetésszerüsége

EGYÜTTMUUK: A piackutató és marketingvezető együittmúködésének intenzitása

MINŐSÉG: A piackutatás észlelt minősége 
eltérő módon kondicionált, különbözô gondolkodási sémákkal rendelkező közösség metaforájának keresztelve. Nyilvánvalóan a két fél kölcsönös megértésén, a közös nyelv kialakításán, egymás problémáinak megértésén keresztül vezet az út a bizalomhoz; erre teremt lehetôséget a piackutató és a marketingvezetố szoros együttmúködése.

A korábbi kutatásokban eddig még nem vizsgálták, hogyan hat a menedzser piackutatóba vetett bizalmának kialakulására az, ha a piackutatás megerósíti a várakozásokat. Eredményeink szerint annál jobban bízik a marketingvezetố a piackutatóban, minél kevésbé meglepetésszerú, minél inkább az intuícióknak megfelelő eredményeket hoz a piackutatás (ld.: 2. táblázat, $M E G$ LEP faktor). Ez egybecseng Moorman - Deshpandé et al. (1993) korábbi ténymegállapításaival, akik szerint a kutatóba vetett bizalomhoz nagymértékben hozzájárul a kutató (kutatás) bizonytalanságcsökkentô képessége, hatása. Az olyan tanulmányok, amelyek megerősítik a várakozásokat, nem bizonytalanítják el a döntéshozót; ezért úgy túnik, hogy ilyenkor a menedzserek jobban megbíznak a piackutatóban, mint amikor az intuícióknak ellentmondó kutatási eredmények születnek. Kutatási eredményeinket alátámasztották mélyinterjú alanyaink is.

Ha a piackutatásban szerepló megállapítások lényegesen eltérnek a várttól ,elkezdesz kötekedni a kutatóval minden olyannal kapcsolatban amivel kötekedhetsz, célcsoport miért ilyen volt, a szúrés miért olyan volt stb.” (FMCG cég márkamenedzsere)

Tanulmányunk ezen eredménye arra is felhívja a figyelmet, hogy a piackutatóknak képzésük során fel kell készülniük arra, hogy a bizalomvesztés megelőzése érdekében megfelelóen kommunikálják azokat az eredményeket, amelyek esetleg váratlanul érhetik a döntéshozókat. Zaltman és Moorman (1988) eredményei szerint a piackutatók általában ismerik a kutatást megrendelố cég belsô viszonyait, nem ,naivak” az esetleges várakozások tekintetében, így az eredmények meglepetésszerüségének, „fogadtatásának” megítélése nem jelenthet problémát. Kutatásetikai dilemmaként vetődhet fel a „kínos”, váratlan eredmények elkendőzésének kérdése. Moorman (1995) szerint az eredmények precíz, tárgyilagos közlése még akkor is építi a bizalmat, ha azok épp rossz színben tüntetik fel a vállalat teljesítményét.

$\mathrm{Az}$ elkészült piackutatás minóségéról kialakított vélemény szintén hatással van a bizalomra ( $l d$.: 2. táblázat, MINÓSEG faktor). Minél jobb minôségúnek tartja a marketingvezető a piackutatást, annál jobban bízik az azt készítő kutatóban. Feltételezésünk szerint a piackutatási információ észlelt minősége hatással van arra, hogy a marketingvezetô mennyire bízik meg a piackutatóban. A bizalom kialakulása hosszabb, interatív folyamat, amelyben a jó szakmai minőségúnek tartott piackutatás lehetséges megerősítési pont. Maltz és Kohli (1996) a részlegek közötti információmegosztást vizsgálva a más részlegen dolgozóba vetett szakmai bizalom kialakulása legfontosabb tényezőjének a kolléga által átadott információ szakmai minőségét találta.

\section{A vállalaton belüli piackutató szerepe a marketingvezetó és a szakosodott piackutató közötti bizalom kialakulásában}

Kutatásunkban tettünk fel kérdést arra vonatkozóan, hogy a vállalaton belül létezik-e önálló piackutató munkakör vagy piackutató osztály. A dichotóm (kétirányú) változót nem vontuk be modellünkbe, de utólag megvizsgáltuk, hogy a bizalom hogyan alakul abban az esetben, ha van és ha nincs piackutató munkakör a szervezeten belül. Ez a kérdés azért is érdekes, mert a témakör korábbi tanulmányaiban nem vizsgálták ezt az összefüggést (3. táblázat).

\section{3. táblázat}

A marketingvezető (külsố)

piackutatóba vetett bizalma a vállalaton belüli piackutatói munkakör tükrében

\begin{tabular}{|l|c|c|c|}
\hline & Átlag & $\begin{array}{c}\text { Szó- } \\
\text { rás }\end{array}$ & $\begin{array}{c}\text { Érvényes } \\
\text { elem- } \\
\text { szám }\end{array}$ \\
\hline Összesen & 24,78 & 7,40 & 138 \\
\hline Van piackutató munkakör a vállalatnál & 22,68 & 8,78 & 43 \\
\hline Nincs piackutató munkakör a vállalatnál & 25,48 & 6,58 & 91 \\
\hline
\end{tabular}

Megjegyzés: A táblázatban a bizalom mérésére szolgáló állítások számtani összegzésével komplex indexet képeztünk, melynek lehetséges maximális értéke 35 , mivel mind a hét változót ötfokozatú skálán mértük.

Kutatásunk tanulsága szerint a bizalom mértékében szignifikáns különbség van azoknál a vállalatoknál, ahol van és ahol nincs belsố piackutató munkakör. A kutatást megrendelő vállalaton belüli piackutató „tolmács” feladatokat lát el a statisztikai terminológiákkal operáló piackutatók és az üzleti problémákban gondolkodó marketingmenedzserek között. Ezért azt várhatnánk, hogy a belsố piackutató segíthet áthidalni a „two communities methaphor" jelenségében leírt kommunikációs nehézségeket. Eredményeink azonban nem támasztják alá ezt a várakozást. Szignifikánsan jobban bíznak azok a marketingvezetốk a piackutatókban, akik olyan vállalatoknál dolgoznak, ahol nincs belsố piackutató munkakör, az átlagnál pedig kevésbé bíznak a piackutató cég 
képviselőjében a menedzserek, ha az együttmúködésbe bekapcsolódik belsố piackutató is. Ez azt jelenti, hogy a menedzser és a piackutató közötti közvetlen együttmúködés fontosabb a bizalom kiépítésében, mint a közös munkát koordináló „tolmács” segítsége.

A 4. táblázat eredményei alapján megállapítható az is, hogy nemcsak a bizalom mértéke, hanem a bizalom kialakulására ható tényezók szerepe is eltérô. A piackutatóval való együttmúködés nagyobb mértékben járul a bizalom kialakulásához, ha van belsố piackutató munkakör. Ha belsố piackutatón keresztül van a marketingvezetố kapcsolatban a külsố piackutatóval, akkor a piackutatás vizsgált sajátosságai (kutatás minősége, meglepetésszerüség) nincsenek szignifikáns hatással a bizalom mértékére. Ez azt jelenti, hogy ha a marketingvezetô az elkészült piackutatást nem az azt készítô cég munkatársától, hanem

\section{A bizalmat meghatározó tényezók a vállalti piackutatói munkakör tükrében - regresszió-elemzés eredményei}

\begin{tabular}{|c|c|}
\hline Vizsgált minta & Regressziós egyenlet \\
\hline $\begin{array}{l}\text { Valamennyi nagyvállalat } \\
\text { (ld.: 2. táblázat) }\end{array}$ & $\begin{array}{l}\text { TRUS }=-, 158 *(\text { MEGLEP })+, 469 * * *(\text { EGYÜTTMÜK }) \\
+, 204 *(\text { MINŐSEG })+\text { e1; }(\text { R négyzet }=, 464)\end{array}$ \\
\hline $\begin{array}{l}\text { Van belsó piackutató } \\
\text { munkakör }\end{array}$ & $\begin{array}{l}\text { TRUS }=, 099 \text { (MEGLEP) }+, 534 * * *(\text { EGYÜTTMÚK }) \\
+, 115(\text { MINŐSEG })+\mathrm{e} 1 ;(\text { R négyzet }=, 387)\end{array}$ \\
\hline $\begin{array}{l}\text { Nincs belsố piackutató } \\
\text { munkakör }\end{array}$ & $\begin{array}{l}\text { TRUS }=, 208 *(\text { MEGLEP })+, 420 * * *(\text { EGYÜTTMÚK }) \\
+, 256 *(\text { MINŐSEG })+\text { e1; }(\text { R négyzet }=, 532)\end{array}$ \\
\hline
\end{tabular}

Szignifikanciaszintek: $* \mathrm{p}<, 05 ; \quad * * \mathrm{p}<, 01 ; \quad * * * \mathrm{p}<0,001$

Jelmagyarázat:

TRUS: A marketingvezetó piackutatóba vetett bizalmának mértéke MEGLEP: A piackutatás eredményeinek meglepetésszerúsége

EGYÜTTMƯKK: A piackutató és marketingvezetô együttmúködésének intenzitása

MINÔSÉG: A piackutatás észlelt minősége

R négyzet: A modell illeszkedésének mérôszáma. Értéke 0-1 között lehet, minél magasabb az értéke, a modell annál jobbnak tekinthető. Az R négyzet értéke megmutatja, hogy a független változók a függó változó teljes varianciájának mekkora részét magyarázzák meg. Malhotra (2001) 726.,732. oldal.

saját piackutató kollégájától kapja kézhez; akkor a tanulmányban szereplő meghökkentő ténymegállapítások, vagy a gyengébbnek talált piackutatási munka nem rendítik meg a külsô kutatóba vetett bizalmat. A kutatás forrásáig, a tanulmány készítőéig nem vezetik vissza a tanulmány minőségi konzekvenciáit, ha a belsô piackutató munkatárson keresztül kapják meg az eredményeket. Ezzel szemben a bizalom rovására megy, ha olyan kutató készít ügyfélismeretet nem tükrözố tanulmányt, akikkel a döntéshozók szorosan együttmúködnek.

\section{Az értéklánc második eleme: a piackutatás észlelt minôsége}

\section{Hogyan vélekednek általában a marketingvezetók az elkészüllt piackutatások minóségéról?}

A piackutatás minőségének vezetôi észlelését nyolc ötfokozatú, Likert-típusú skála segítségével mértük. Állításokat fogalmaztunk meg a piackutatással, a prezentációval és a vezetői összefoglalóval kapcsolatosan, illetve kíváncsiak voltunk a kutatás technikai (pl. ábrák, statisztikák elhelyezése, az interpretáció érthető megfogalmazása stb.) és szakmai minőségével (pl. információgyúijtés kivitelezése stb.) kapcsolatos véleményekre (5. táblázat).

Eredményeink szerint a marketingvezetốk összességében pozitívan ítélik meg a külső szakosodott szolgál-

4. táblázat tatókáltal készített piackutatások minôségét. A legpozitívabban a prezentáció érthetőségével és szakmai minőségével kapcsolatosan alkottak véleményt. A vélemények a legnagyobb mértékben a vezetôi összefoglaló megítélésénél tértek el az átlagtól, azonban ennél az állításnál is inkább kedvezó a marketing-döntéshozók álláspontja.

Két állítást fogalmaztunk meg ,negatív" formában. A vállalatvezetók szerint általában nem jellemző, hogy a piackutatási jelentésben zavaró ellentmondások szerepelnének, ugyanakkor - ha közepes mértékben is - de jellemzónek tartják, hogy túl sok adat, táblázat vagy ábra szerepel a tanulmányokban.

Az eredményeket tovább gondolva megfogalmazhatjuk, hogy a marketing-döntéshozók elégedettek a piackutatók munkájával. Elgondolkodtató azonban a vezetôi összefoglaló nagyobb szórást mutató megítélése. Sok döntéshozó véli úgy, hogy a tanulmányokban a szükségesnél részletesebben „terhelik” ôket statisztikai részletekkel. A kutatást megelőzố mélyinterjú-sorozatunkból kitúnt, hogy egy megfelelő szakmai színvonalú vezetôi összefoglaló elkészítése bonyolult és strukturálatlan feladat. A döntéshozók sokszor többet várnak a tanulmány fóbb ténymegállapításainak felsorolásánál (artikulált igény, hogy a vezetôi összefoglaló elolvasása elegendő legyen ahhoz, hogy a vezető „képbe kerüljön" a tanulmánnyal kapcsolatosan).

„Legyen egy rövid összefoglalója, amiból kiderül a lényeg. Ha csak azt a pár oldalt olvasom el, akkor is kapjak egy kis összefoglalót. Ne legyen benne blabla, hanem számszerú legyen! Nekem ez a legfontosabb paraméter, ami meghatározza, hogy jó-e egy piackutatás." (FMCG kozmetikai cikkek, marketingigazgató) 
A piackutatás minőségének vezetôi megítélése - alapstatisztika

\begin{tabular}{|c|c|c|c|c|c|c|c|c|c|c|}
\hline & \multirow{2}{*}{$\begin{array}{l}\text { Terje- } \\
\text { delem }\end{array}$} & \multicolumn{7}{|c|}{ Gyakoriság } & \multirow{2}{*}{$\begin{array}{l}\text { Át- } \\
\text { lag }\end{array}$} & \multirow{2}{*}{$\begin{array}{c}\text { Szó- } \\
\text { rás }\end{array}$} \\
\hline & & 1 & 2 & 3 & 4 & 5 & NT/NV & $\Sigma$ & & \\
\hline A piackutatás, illetve a prezentáció érthető, követhető volt & $2-5$ & 0 & 4 & 9 & 91 & 68 & 166 & 338 & 4,3 & 67 \\
\hline A piackutatásban túl sok táblázat, ábra és statisztika szerepelt & $1-5$ & 19 & 78 & 43 & 22 & 9 & 167 & 338 & 2,52 & 1,02 \\
\hline Az eredmények értelmezése, magyarázata helytálló volt & $2-5$ & 0 & 8 & 33 & 99 & 30 & 168 & 338 & 3,84 &, 85 \\
\hline A vezetői összefoglaló jó színvonalú volt & $1-5$ & 3 & 11 & 30 & 89 & 32 & 174 & 338 & 3,69 & 1,12 \\
\hline A piackutatás megérte a ráfordítást & $1-5$ & 6 & 11 & 35 & 72 & 43 & 171 & 338 & 3,76 & 1,09 \\
\hline Az információgyújjtés kivitelezése megfelelő volt & $1-5$ & 2 & 6 & 24 & 93 & 39 & 174 & 338 & 3,84 & 1,08 \\
\hline A piackutatás szakmai minősége jó volt & $1-5$ & 1 & 2 & 28 & 101 & 38 & 168 & 338 & 4,02 & ,70 \\
\hline A jelentésben számos zavaró ellentmondás volt & $1-5$ & 53 & 97 & 10 & 5 & 3 & 170 & 338 & 1,84 &, 82 \\
\hline
\end{tabular}

Megj.: 1 = egyáltalán nem jellemző; 5 = teljes mértékben jellemző A piackutatással kapcsolatos kérdések megválaszolására csak azokat a marketingvezetóket kértük, ahol az elmúlt öt évben készült piackutatás; ez indokolja a NT/NV kategóriában szerepló magas értékeket. Adatbázisunkban a 338 megkérdezett vállalat közül 174 olyan vállalat volt, ahol készült piackutatás az elôző öt esztendóben.

A túl sok adat, statisztika épp a kutatók mechanisztikus, „termelésorientált” hozzáállására utal, vagyis előfordulhat, hogy nem értik meg teljes mélységében az ügyfél problémáját, és nem arra próbálnak megoldást találni, hanem „csupán” az adatokat „korrekten” elemezni és értelmezni.

A tanulmány minőségével kapcsolatos állítások értelmezése alapján tehát elmondhatjuk, hogy az alapvető elégedettség mellett latens módon megfogalmazódik a „problémaorientált” és kreatív hozzáállás iránti igény is.

\section{A piackutatás minôségéról kialakított véleményt meghatározó tényezók}

Regresszióelemzés segítségével vizsgáltuk meg, mely tényezók vannak hatással arra, hogyan vélekedik a marketingvezetố az elkészült piackutatás minőségéról.

A piackutatás szúk értelemben vett szakmai sajátosságainak (adatgyuújtés, mintanagyság, elemzés, interpretáció minósége stb.) megítélésére hatással van, hogy a tanulmány eredményei mennyire igazolják az elôzetes várakozásokat. Eredményeink szerint a meglepetésszerü kutatási eredmények rontják a kutatás szakmai minőségének megítélését. A kutatást megelőző mélyinterjúk során alanyaink is tettek olyan kijelentéseket, amelyek a váratlan piackutatási eredmények a minôség megítélésére gyakorolt romboló hatását támasztják alá.

„Mikor tartok jó minőségúnek egy kutatást? Ha csökkenti a kérdőjeleket és a félelemérzetet a döntéseknél." (Telekommunikációs vállalat piackutató munkakörében dolgozó szakembere)

„A jó kutatás azt az eredményt hozza, amit vártam.” (Élelmiszeripar területén múködő FMCG márkamenedzser)
A piackutatás minőségének észlelését eredményeink szerint rontja, ha a tanulmányban olyan ténymegállapítások szerepelnek, amelyek hátrányos helyzetbe hoznak, vagy kellemetlenül érintenek munkatársakat vagy részlegeket. Vagyis ahhoz, hogy egy piackutatást jó minőségünek tartson a marketingvezetô, nemcsak szakmai kritériumoknak kell megfelelnie, de a vállalat ,politikai erőterén" belül is elfogadhatónak kell lennie. Ezt az öszszefüggést a korábbi tanulmányok nem vizsgálták, érdekes tanulságokkal szolgálhat a magyar vezetốk szolidáris magatartása mögött húzódó okok feltárása.

A piackutatás minôségének megítélését paradox módon mégsem a kutatási tanulmány vizsgált sajátosságai (meglepetésszerúség, politikai elfogadhatóság), hanem a marketingvezetố és a kutató közötti bizalmi viszony határozza meg. A tanulmány késóbbi felhasználója sokszor nem ismeri a kutatás lebonyolításának

6. táblázat

\section{A piackutatás minőségéról \\ kialakított véleményt meghatározó tényezók - a regresszióelemzés eredményei}

\begin{tabular}{|c|c|}
\hline Független változók & Regressziós együttható (t-érték) \\
\hline ELFOGAD &,$- 223^{* *}(-3,357)$ \\
\hline MEGLEP &,$- 218^{* *}(2,768)$ \\
\hline BIZALOM &, $329^{* * *}(4,429)$ \\
\hline DÖNTES &, $346^{* * *}(4,871)$ \\
\hline F érték & $26,246^{* * *}$ \\
\hline R négyzet &, 451 \\
\hline
\end{tabular}

Szignifikanciaszintek: $* \mathrm{p}<, 05 ; \quad * * \mathrm{p}<, 01 ; \quad * * * \mathrm{p}<0,001$ Jelmagyarázat:

ELFOGAD: A piackutatás eredményei elfogadhatók a vállalat „politikai” erôterén belül, nem hoznak kellemetlen helyzetbe munkatársakat. MEGLEP: A piackutatás eredményeinek meglepetésszerúsége BIZALOM: A marketingvezető piackutatóba vetett bizalma DÖNTÉS: A piackutatás döntéshozatalhoz kapcsolódó felhasználása 
körülményeit és a módszertani, statisztikai ismeretek tekintetében fennálló különbségek is megnehezítik, hogy a döntéshozó objektíven meg tudja ítélni a kutatás minőségét. Lee - Acito et al. (1987) tanulmányukban azt vizsgálták, van-e különbség a piackutatások minôségének megítélésében, ha a kutatás során a módszertan megfelel a szakmai kritériumoknak, és ha nem. Eredményük szerint a minôség megítélésére nem volt hatással az alkalmazott módszertan; a kutató által követett mintavételi módszer és a mintanagyság sem befolyásolta a minőség észlelését. A felek közötti bizalmi viszony azért fontos a minőség megítélésében, mert a piackutató döntéseket hoz olyan tanulmányok alapján, amelyek elkészítésének körülményeit és szakmai minőségét a felek között fennálló információs aszimmetria miatt csak korlátozottan ismerhet.

Az információ minőségének vezetối megítélésére hatással van az is, hogy a piackutatás a késóbbiekben támogatta-e döntések meghozatalát. Ezt az összefüggést korábban csak Maltz és Kohli (1996) vizsgálta. Tanulmányukban a piaci információk munkatársak közötti megosztását vizsgálták, nem találva összefüggést a piaci értesülések naprakészségének, akkurátusságának, minőségének utólagos megítélése és az információk marketingmenedzsment-munkában történô felhasználása között. Kutatásunkban a piaci megfigyeléseknél és értesüléseknél sokkal formálisabb és költségesebb információkat, a piackutatásokat vizsgáltuk. A piaci „,pletykáknál" ráfordítás igényesebb piackutatás esetében az önigazolás - hogy valóban megérte a szolgáltatást elkészíttetni - is magyarázhatja, hogy a minőség megítélésére hatással van, támaszkodott-e a kutatási jelentésre a marketingvezetố. Ez az összefüggés egyben arra is ráirányítja a figyelmet, hogy a piackutatónak érdemes „follow-up” jellegúen követni a piackutatás sorsát.

Eredményeink rámutatnak arra, hogy a piackutatás minőségének észlelése nem esemény, hanem hosszabb folyamat. Ez a folyamat már megkezdődik a piackutatóról vallott kép és bizalmi viszony kialakításával - ez időben a kutatási projekt elejéhez kötődik, amikor a pi- ackutatás outputja, a tanulmány még közel sem készült el. A kutatás minôségének megítélése ugyanakkor nem zárul le a tanulmány elkészülttével és a kutatási projekt befejezésével, hiszen a kutatás döntéshozatali munkálatok során történő felhasználása „visszahat” a minőség észlelésére.

\section{Az értéklánc harmadik és negyedik eleme: a piackutatások hasznosulása a döntéshozatalban és a piaci tanulás során}

\section{Milyen mértékben használják fel a marketingvezetók a piackutatásokból származó információkat?}

Az információ döntéshozatalhoz kapcsolódó felhasználása alatt Caplan - Morisson et al. (1975) nyomán a piackutatás egy jól körülhatárolható probléma megoldásához kötôdő közvetlen felhasználását értjük. Vagyis létezik egy vezetôi probléma, és a piaci információk, a piackutatás eredményei nagymértékben befolyásolják azt, hogy milyen döntés születik. A tanuláshoz kötődó információfelhasználás alatt a piackutatásnak egy kérdéskör mélyebb megértése érdekében, háttérismeretként történố alkalmazását értjük (Beyer - Trice, 1982). Ennél a felhasználási módnál a marketing-döntéshozó a piackutatáson keresztül tanul a piacról, a piackutatásból absztraktabb, a piackutatás szúk értelemben vett ténymegállapításain túlmutató ismeretekkel gazdagodik, a kutatás hozzájárul ahhoz, hogy a döntéshozó elgondolkodjon egy jelenség mélyebb összefüggésein.

Tanulmányunkban Menon és Wilcox (2001), valamint Deshpandé (1982) skáláit adaptálva fogalmaztunk meg állításokat a piackutatások marketingmenedzsment-munkában történô felhasználásával kapcsolatosan. A 7. táblázatban azokat az állításokat láthatjuk, amelyek a piackutatások közvetlen, körülírható problémák megoldására vonatkoznak, és a döntéshozatalt segítik, míg a 8. táblázatban található állítások azt mutatják, hogy a marketingvezetốk tanultak-e valamit a piackutatásokból (7. táblázat).

7. táblázat

A piackutatási információ döntéshozatalhoz kapcsolódó felhasználása - alapstatisztikák

\begin{tabular}{|c|c|c|c|c|c|c|c|c|c|c|}
\hline \multirow{2}{*}{$\begin{array}{l}\text { Döntéshozatalhoz kapcsolódó információ- } \\
\text { felhasználás }\end{array}$} & \multirow{2}{*}{$\begin{array}{l}\text { Terje- } \\
\text { delem }\end{array}$} & \multicolumn{7}{|c|}{ Gyakoriság } & \multirow{2}{*}{ Átlag } & \multirow{2}{*}{$\begin{array}{l}\text { Szó- } \\
\text { rás }\end{array}$} \\
\hline & & 1 & 2 & 3 & 4 & 5 & NT/NV & $\Sigma$ & & \\
\hline $\begin{array}{l}\text { Érdemes volt a kutatást megvárni, mert eredmé- } \\
\text { nyei jelentősen befolyásolták döntéseinket }\end{array}$ & $1-5$ & 5 & 29 & 66 & 32 & 8 & 3 & 143 & 3,00 & ,99 \\
\hline $\begin{array}{l}\text { A tanulmány ténymegállapításaira támaszkodva } \\
\text { hoztunk meg döntéseket }\end{array}$ & $1-5$ & 4 & 7 & 51 & 64 & 16 & 1 & 143 & 3,55 & ,91 \\
\hline $\begin{array}{l}\text { A kutatásból származó információk többségét } \\
\text { felhasználtuk a döntéshozatalnál }\end{array}$ & $1-5$ & 4 & 7 & 36 & 79 & 16 & 1 & 143 & 3,69 & 87 \\
\hline
\end{tabular}


Eredményeink szerint az elkészült piackutatások megközelítóleg kétharmada kap fontos szerepet a döntéshozatal során, ugyanakkor a tanulmányok átlagosan hat-tíz százalékát nem veszik figyelembe a marketingmenedzsment-munkában a döntéshozók. A kutatás eredményei ritkábban befolyásolják, vagy módosítják jelentősen (a megkérdezett esetek kevesebb mint 30 százaléka) a döntéshozatalt ami a piackutatások döntésmegerôsítố szerepére utal (8. táblázat).
A munkakör formalizáltságának információfelhasználásra gyakorolt hatását több, korábbi kutatás is vizsgálta - egymásnak ellentmondó eredményekkel. Deshpandé (1982) szerint minél jobban körülírt egy marketingmenedzser munkaköre, annál kevésbé támaszkodik a piackutatásokra a döntéshozatalban. A hipotézis megfogalmazása során Deshpandé (1982) a munkakör specifikusságát a szervezeti formalizáltság egyik dimenziójaként kezeli, és hipotézisét a szervezeti

8. táblázat

A piackutatási információ tanuláshoz kapcsolódó felhasználása - alapstatisztikák

\begin{tabular}{|c|c|c|c|c|c|c|c|c|c|c|}
\hline \multirow{2}{*}{ Tanuláshoz kapcsolódó információ-felhasználás } & \multirow{2}{*}{$\begin{array}{l}\text { Terje- } \\
\text { delem }\end{array}$} & \multicolumn{7}{|c|}{ Gyakoriság } & \multirow{2}{*}{ Átlag } & \multirow{2}{*}{$\begin{array}{l}\text { Szó- } \\
\text { rás }\end{array}$} \\
\hline & & 1 & 2 & 3 & 4 & 5 & NT/NV & $\Sigma$ & & \\
\hline $\begin{array}{l}\text { A piackutatás sok kérdést vetett fel, melyek új lehetôségek } \\
\text { feltárásában segítettek }\end{array}$ & $1-5$ & 9 & 63 & 42 & 29 & 2 & 1 & 146 & 2,65 & ,94 \\
\hline Lehetséges, a kutatás nélkül eltéró módon gondolkodtunk volna & $1-5$ & 6 & 47 & 53 & 30 & 6 & 1 & 143 & 2,86 & ,96 \\
\hline $\begin{array}{l}\text { A kutatás eredményeit felhasználtuk arra is, hogy valami újat } \\
\text { tanuljunk piacunkról }\end{array}$ & $1-5$ & 2 & 8 & 28 & 81 & 25 & 1 & 145 & 3,80 & ,89 \\
\hline A piackutatás készítése során sokat tanultam & $1-5$ & 5 & 30 & 44 & 54 & 10 & 3 & 146 & 3,17 & 1,07 \\
\hline
\end{tabular}

Válaszadóink többsége úgy ítéli meg, hogy a piackutatások elkészítéséból és az eredmények átgondolásából, értelmezéséból lehet tanulni. Ugyanakkor arra az állításra, amely konkrétan arra kérdezett, hogy a legutóbbi piackutatás segített-e új lehetôségek feltárásában többen adtak negatív (egyáltalán nem és nem), mint pozitív (igen és teljes mértékben) választ.

\section{A piackutatásoknak a döntéshozatalban és a piaci tanulás során történó felhasználását meghatározó tényezók}

\section{A döntéshozatal}

Feltételezésünk szerint a piackutatás döntéshozatalhoz kötődő felhasználására az információ és a szervezet sajátosságai, valamint az információ tanuláshoz kötódó felhasználásának mértéke vannak hatással. Az összefüggéseket regresszióelemzéssel vizsgáltuk, ennek eredményeit a 9. táblázatban közöljük (9. táblázat).

Eredményeink szerint minél formálisabban körülírt munkakörben dolgozik egy marketingvezetó, annál jobban támaszkodik a döntéshozatal során a piackutatásokra. A munkakör formalizáltsága egyfajta rendet, rutint és szigort visz a marketingmenedzsmentbe, így a formális munkafolyamatok, a körülírt feladatkörök - amelyek komplex döntési helyzetekben pontosan meghatározhatják a mérlegelendó információk körét - esetében kisebb a valószínúsége annak, hogy egy piackutatás ténymegállapításai ,elsikkadjanak”. innováció irodalmára visszanyúlva építi fel. Zaltman Duncan et al. (1973) innovációval kapcsolatos kutatásai szerint a formális rutinok szerint múködő vállalatok innovációs képessége elmarad az informálisabb alapon szerveződô vállalatokétól. Mivel Deshpandé (1982) szerint egy új piackutatásból származó információ jelensége megfeleltethetô az innováció adaptálásának jelenségével, feltételezhetô, hogy a formalizáltság negatívan hat a folyamatra. A szervezeti formalizáltság és a döntéshozatalhoz kapcsolódó információfelhasználás közötti negatív kapcsolatot a szerzốpáros több ké-

\section{A piackutatás döntéshozatalhoz kapcsolódó információfelhasználását meghatározó tényezók - a regresszióelemzés eredményei}

\begin{tabular}{|c|c|}
\hline Független változók & Regressziós együttható (t-érték) \\
\hline FORMAL &, $165^{* *}(2,434)$ \\
\hline MINŐSÉG &, $366^{* * *}(5,235)$ \\
\hline TANULÁS &, $358^{* * *}(5,062)$ \\
\hline F érték & $30,812 * * *$ \\
\hline R négyzet &, 408 \\
\hline
\end{tabular}

Szignifikanciaszintek: $* \mathrm{p}<, 05 ; * * \mathrm{p}<, 01 ; * * * \mathrm{p}<0,001$

Jelmagyarázat:

FORMAL: Formalizáltság, mennyire múködik a vállalat formális, írásban rögzített szabályok szerint MINŐSÉG: A piackutatás észlelt minősége

TANULÁS: A piackutatás tanuláshoz kapcsolódó információ felhasználása 
sốbbi kutatásaikban (Deshpandé, 1982; Deshpandé Zaltman, 1982; Deshpandé - Zaltman, 1984; Deshpandé - Zaltman, 1987) szintén validálták.

John és Martin (1984) a marketingtervek döntéshozatalhoz kötődő felhasználását vizsgálva a Deshpandé - Zaltman szerzópárossal ellentétes eredményekre jutott. Kutatásuk szerint minél formalizáltabb ${ }^{4}$ egy munkakör, annál nagyobb mértékben fog a terv a marketingmenedzsment munkájában hasznosulni. Maltz és Kohli (1996) a vállalati részlegek közöttiinformációmegosztás formálisságát vizsgálva azt találta, hogy minél formálisabb módon történik az információk megosztása, annál nagyobb mértékben hasznosulnak a marketingrészlegen a más részlegektől származó információk. Low és Mohr (2001) szintén pozitív kapcsolatot talált a formalizáltság és az információhasznosulás ${ }^{5}$ között. Kohli és Jaworski (1990) ugyanakkor a formalizáltság és a szervezeti piacorientáció - amelynek egyik pillére a piaci intelligenciára való válaszadás, vagyis a piaci értesülések, megfigyelések hasznosulása a marketingmenedzsmentben - között nem talált szignifikáns kapcsolatot.

Eredményeink alapján nem tudunk közvetlen kapcsolatot kimutatni azinstrumentális információfelhasználás és a piackutatóba vetett bizalom között, vagyis nem igaz az, hogy minél jobban bízik a marketingvezetó a piackutatóban, annál nagyobb mértékben támaszkodik a piackutatásra. Ugyan erre az eredményre jutott Moorman - Zaltman et al. (1992) is, akik a bizalom és az információfelhasználás közötti kapcsolatot tovább vizsgálták. Útelemzést (path analysis) végezve kimutatták, hogy jóllehet közvetlenül valóban marginális a piackutatóba vetett bizalom információfelhasználásra gyakorolt hatása, más változókon keresztül, közvetve mégis az egyik legfontosabb tényezó. Eredményeink alátámasztják a korábbi megállapításokat: a piackutatóba vetett bizalom a legfontosabb tényezô a piackutatás minőségének észlelésében, ugyanakkor a piackutatás minősége a legfontosabb (vizsgált) tényezô az információ instrumentális felhasználásában.

Kutatásunk szerint minél jobb minőségúnek találja a marketingvezetố az elkészült piackutatást, annál nagyobb mértékben támaszkodik arra a döntéshozatal során. O'Reilly (1982) szerint az információ instrumentális hasznosulásának egyik legfontosabb meghatározója az információ minősége. Az információ észlelt minőségének és az információfelhasználásnak a kapcsolatát több korábbi kutatás is igazolta (Deshpandé - Zaltman, 1982, 1984; Lee - Acito et al., 1987; Menon - Varadarajan, 1992; Maltz - Kohli, 1996, 2001; Low - Mohr, 2001).

A korábbi kutatások nem vizsgálták a döntéshozatalhoz és piaci tanuláshoz kapcsolódó információfelhasználás kapcsolatát. Azt feltételezzük, hogy ha egy marketingvezető komolyan elgondolkodik egy piackutatás eredményeinek értelmezése során, akkor - mivel a tanulmány tartalmát, összefüggéseit mélyebben megismerte - nagyobb mértékben fog arra támaszkodni, mint egy olyan tanulmányra, amelyet felszínesebben ismer csupán.

\section{Piaci tanulás}

Feltételezésünk szerint a piackutatóval történő együttmúködés mértéke és a piackutatások döntéshozatali munkában való felhasználása határozza meg, hogy mennyit tanul egy marketingvezetố a piackutatásból. $\mathrm{Az}$ összefüggéseket regresszióelemzéssel vizsgáltuk. Eredményeink szerint a vizsgált két (együttmúködés mértéke és a piackutatások felhasználása a döntéshozatalnál) tényező 27 százalékban magyarázza, miért tanulnak bizonyos marketingvezetók többet más vállalatok szakembereinél a piackutatási projekt lebonyolítása során (10. táblázat).

10. táblázat

A piackutatás tanuláshoz kapcsolódó

információfelhasználását meghatározó tényezók - a regresszióelemzés eredményei

\begin{tabular}{|l|c|}
\hline Független változók & Regressziós együttható (t-érték) \\
\hline EGYÜTTMÜKÖDÉS &, $138(1,814)$ \\
\hline DÖNTÉS &, $468 * * *(6,164)$ \\
\hline F érték & $25,784 * * *$ \\
\hline R négyzet &, 273 \\
\hline
\end{tabular}

Szignifikanciaszintek: ${ }^{*} \mathrm{p}<, 05 ; \quad * * \mathrm{p}<, 01 ; * * * \mathrm{p}<0,001$ Jelmagyarázat:

EGYÜTTMŰK: A piackutató és marketingvezető együttmúköóésének intenzitása

DÖNTÉS: A piackutatás döntéshozatalhoz kapcsolódó információ felhasználása

Tanulmányunkban hipotézisként megfogalmaztuk, hogy a piackutatóval való együttmúködés során a marketingvezetố is rákényszerül arra, hogy a kutatási problémával kapcsolatos ismereteit rendszerezze, így feltettük, hogy minél kiterjedtebb az együttmúködés, annál nagyobb mértékú az információ fogalmi hasznosulása. Eredményeink azonban nem támogatták feltételezésünket, $(\mathrm{b}=, 138, \mathrm{p}=$ n.s., ld.10. táblázat), mivel a két tényező között ugyan pozitív kapcsolat van, de a szignifikanciaszint nem elfogadható. A piackutatóval történő együttmúködés piaci összefüggések felismerésében, új lehetôségek feltárásában betöltött szerepét részmintákon is teszteltük. A regressziós egyenletet teszteltük olyan vállalatok körében, ahol önálló piackutató osztály vagy munkakör létezik és ahol nem létezik (11. táblázat). 


\section{A piackutatás tanuláshoz}

kapcsolódó információ felhasználását meghatározó tényezók a vállalaton belüli piackutatói munkakör tükrében

\begin{tabular}{|c|c|}
\hline Vizsgált minta & Regressziós egyenlet \\
\hline $\begin{array}{l}\text { Valamennyi nagyvállalat } \\
\text { (ld.: 9. táblázat) }\end{array}$ & $\begin{array}{l}\text { TANULÁS }=, 138(\text { EGYÜTTMÜK })+468 * * * \\
(\text { DÖNTÉS })+e 4(\text { négyzet }=, 273)\end{array}$ \\
\hline $\begin{array}{l}\text { Van belső piackutató } \\
\text { munkakör }\end{array}$ & $\begin{array}{l}\text { TANULÁS }=, 141(\text { EGYÜTTMÚK) }+446 * * * \\
(\text { DÖNTÉS)+ e4 }(\text { R négyzet }=, 191)\end{array}$ \\
\hline $\begin{array}{l}\text { Nincs belsố piackutató } \\
\text { munkakör }\end{array}$ & $\begin{array}{l}\text { TANULÁS }=, 280 * *(\text { EGYÜTTMÚK })+444 * * * \\
(\text { DÖNTÉS })+\text { e4 }(\mathrm{R} \text { négyzet }=, 352)\end{array}$ \\
\hline
\end{tabular}

„Van egy olyan kutatásunk, amelyik általános piacbővítő ismereteket nyújt. Megcsináljuk; szuper, de nagyon kevés döntéshez használjuk fel. Még csak el se olvassa mindenki. Nincs elég időnk, vagy hanyagság, nem tudom, hogy mi az oka." (Kozmetikai cikkekkel foglalkozó, marketingigazgatóként dolgozó interjúalany)

Feltételezhetjük, hogy a marketing-döntéshozó nem motivált, nincs rákényszerítve arra, hogy mélyebben is megismerje, elgondolkodjon az olyan kutatásokon, amelyek nem egy konkrét vezetói problémához kötốdnek, vagy amely mögött nincs valós információhiány.

Azoknál a vállalatoknál, ahol nincsen belsố piackutató munkakör, igazolható a hipotézis (EGYÜTTMÜK faktor értéke szignifikáns), miszerint minél szorosabb az együttmúködés a külsố piackutató és a marketingvezetô között, annál többet tanulnak a piacról a kutatás kapcsán. Ugyanakkor azoknál a vállalatoknál, ahol van belsố piackutató osztály, ott a kapcsolat nem áll fenn (EGYÜTTMÚKK faktor értéke nem szignifikáns).

A belsó piackutató munkakör léte tehát moderáló hatással van az együttmúködés mennyisége és a tanulás kapcsolatára. Ha van belsố piackutató munkakör a szervezetnél, a menedzserek piacról való tanulására nincs hatással a külső piackutatóval történô együttmúködés szorossága. Ezzel szemben, ahol nincs belsô piackutató munkakör, ott minél szorosabban múködik együtt a kutatási projekt során a marketingvezetố és a külsố piackutató, annál többet képes hasznosítani - az adott problémán túlmutatóan is - a kutatás ténymegállapításaiból a vezetố. Meglepó - bár nem szignifikáns eredmény az is, hogy azoknál a vállalatoknál, ahol van belső piackutató munkakör, az együttmúködés mértéke és a fogalmi információfelhasználás között enyhén negatív a kapcsolat.

Mivel kutatásunk az első olyan, amely piackutatásokhoz kapcsolódóan vizsgálja - egy modell keretein belül - a döntéshozatalhoz és piaci tanuláshoz kapcsolódó információfelhasználás jelenségét, értelemszerúen szúkebb szakirodalmi bázis alapján állíthattunk csak fel hipotéziseket a piaci tanuláshoz kötődő információ felhasználással kapcsolatosan. Jóllehet mindössze egy olyan változót - mégpedig a döntéshozatal során történô információfelhasználást - találtunk, amely hatással van a piaci tanulásra, az eredmények tágabb kontextusban is interpretálhatók.

Eredményeink azt jelentik, hogy a piaccal kapcsolatos tanulás az adatok, tények alapos megismerésén, és a marketingmenedzsment-munkába való közvetlen beépülésén keresztül vezet. Ezt az empirikus felmérést megelőző mélyinterjúk tanulságai is megerősítették.
A marketing területén több kutató (Barabba Zaltman, 1991; Haeckel, 1987) is foglalkozott azzal a kérdéssel, hogyan, milyen mechanizmusokon keresztül, milyen „értéklánc” mentén konvertálhatók a piaccal kapcsolatos elemi adatok piaci tudássá. Mind Barabba és Zaltman (1991), mind Haeckel (1987) modellje hierarchikus kapcsolatot vázol a piaci adat, információ és tudás között, vagyis a két szerzőpáros egyetért abban, hogy a piaci információ szükséges - de nem elégséges - feltétele a piaci tudás, bizonyosság kialakulásának.

Haeckel (1987) modellje (4. ábra) hierarchikusan, piramisszerúen ábrázolja az adat-információintelligencia -tudás-bölcsesség láncot. Az adattól a bölcsesség felé haladva az értékük a vállalat számára egyre nagyobb, míg a mennyiségük, volumenük csökken. A modellben megfogalmazódik az a gondolat, hogy az elemi adatok és a bölcsesség között közvetetten van összefüggés. Haeckel (1987) a piaci adattól a piaci „bölcsességig” vezető folyamatban olyan tevékenységeket jelöl meg, mint a kontextusba helyezés, szintézis, következtetések levonása.

\section{4. ábra}

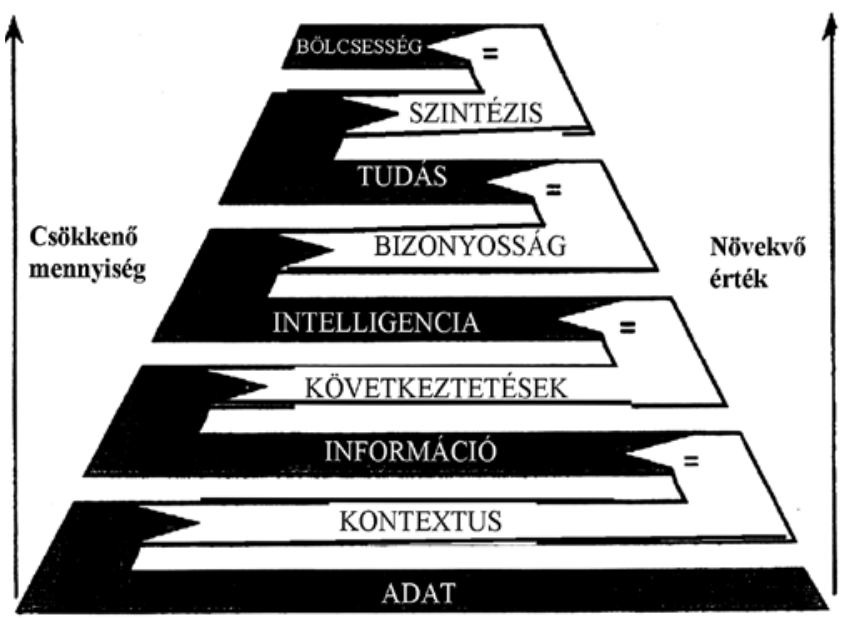

Forrás: Haeckel (1987):45.

\section{Haeckel információhierarchia modellje}


Jelen kutatásunk eredményei szintén arra utalnak, hogy a piaci tudáshoz a piaci információkon keresztül vezet az út, pontosabban a piaci információk közvetlen felhasználásán (kontextusba helyezésén) keresztül.

\section{A kutatás módszertana}

\section{A méróeszköz kialakitása, tesztelése}

Felmérésünk egy nagyszabású, az OTKA támogatásával ${ }^{8}$ készültt, a magyarországi vállalatok marketing-információrendszerét felméró vizsgálat adatbázisán alapul.

A mérőeszközt a felmérést megelőzôen Curchill (1979) iránymutatásait figyelembe véve különböző teszteknek vetettük alá, hogy az esetlegesen elóforduló hibákat kiszúrjük, és hogy olyan kérdőívet kapjunk, amelyek alkalmasak a piackutatás felhasználásának valósághú, megbízható vizsgálatára.

A végleges kérdőív kialakításánál támaszkodtunk a szakirodalomban fellelhetô, korábban alkalmazott - és a fóleg amerikai üzleti környezetben megbízhatónak bizonyult - skálákra, kérdésekre. A felmérést megelózố kvalitatív kutatássorozatban - amikor 6 vállalatnál összesen 20 szakemberrel készítettünk mélyinterjúkat a marketing-információrendszer témakörében - felmerült szempontok alapján a saját fejlesztésú állításokkal is kiegészítettük kérdőívünket. A mérôeszközt két „,körben” teszteltük. A tesztelés első́ etapjában két akadémiai szakembert kértünk a kérdőív elsố változatának tartalmi, illetve formai tesztelésére, értékelésére. A tesztelés második fázisában marketing-szakirányos MBA-hallgatókkal töltettük ki pilot-jellegúen a kérdőívet, arra kérve óket, jelöljék meg azokat az állításokat, amelyek megválaszolása nehézséget okozott. A tesztelések eredményei alapján módosítottuk a kérdőívet.

A 12. táblázatból látható, hogy valamennyi a modellbe beépített absztrakt jelenséget több állítás segítségével mértünk; és a táblázatból kitúnik, hogy a konstrukciók megbízhatóságát ${ }^{9}$ jelző Cronbach-Alpha mérôszám valamennyi konstrukció esetében megfelelő.

\section{Adatgyüjtés}

Modellünket többváltozós statisztikai módszerek segítségével állítottuk fel egy nagyvállalatokkal kapcsolatos információkat tartalmazó adatbázis alapján. Az adatbázis, amelyet 2003 nyarán készítettünk a Központi Statisztikai Hivatal (KSH) Cégkódtár 2003/I. negyedéves kiadványán, mint mintavételi kereten alapul. A 972 nagyvállalatot ${ }^{11},{ }^{12}$ tartalmazó potenciális mintából végül 254 választ kaptunk, mely 26 százalékos válaszadási aránynak felel meg. Adatainkat önkitöltós kérdőív segítségével gyújtöttük, amelyet postai úton juttattunk el válaszadóinknak. A levelek postai kiküldését megelőzően a vállalatok egy részével e-mailen keresztül vettük fel a kapcsolatot a kutatásban való együttmúködésüket kérve. A kutatásban megcélzott valamennyi olyan vállalatot, amely késlekedett a válaszadással, telefon útján személyesen is megkerestük.

Elemzésünkból kizártuk azokat a vállalatokat, amelyek az elmúlt öt évben egyáltalán nem készítettek piackutatást. Kutatásunk megkezdése előtt értékeltük a nem válaszolásból eredő esetleges hibákat. Armstrong és Overton (1977) útmutatásai alapján jártunk el, akik szerint a lényeges leíró (pl. a vállalat előállított termékek/szolgáltatások típusa, üzletág, alkalmazottak száma, tulajdonosi szerkezet), illetve a modellbe bevont változók és a válaszadás „gyorsasága” közötti összefüggések, korrelációk utalhatnak arra, hogy bizonyos típusú vállalatok nem, vagy nehezen érhetók el - és ez szisztematikus hibát eredményez. A vállalatok telefonos megkeresése során kiderült, hogy a válaszadás elutasításának leggyakoribb okai a túl hosszúnak tartott kérdő́ivvel (összesen 10 A4-es oldal) és a válaszadó időhiányával voltak összefüggésben. A statisztikai

12. táblázat

A kutatásban alkalmazott skálák összefoglaló statisztikái

\begin{tabular}{|c|c|c|c|c|c|}
\hline A vizsgált konstrukció & $\begin{array}{c}\text { A méréshez használt } \\
\text { állítások száma }\end{array}$ & Átlag & Szórás & $\begin{array}{l}\text { Terje- } \\
\text { delem }\end{array}$ & $\begin{array}{c}\text { Cronbach Alpha } \\
\text { mérôszám }\end{array}$ \\
\hline Döntéshozatalhoz kapcsolódó információ felhasználás & 3 & 3,41 & 0,922 & $1-5$ &, 75 \\
\hline Piaci tanuláshoz kapcsolódó információ felhasználás & 3 & 3,50 & 1,02 & $1-5$ &, 65 \\
\hline A piackutatás észlelt minősége & 7 & 3,62 & 0,88 & $1-5$ &, 74 \\
\hline A piackutatóba vetett szakmai bizalom & 5 & 3,45 & 1,32 & $1-5$ &, 84 \\
\hline A piackutatás politikai elfogadhatósága & 2 & 1,70 & 0,88 & $1-5$ &, 62 \\
\hline A piackutatás eredményeinek várthoz való igazodása & 2 & 3,50 & 1,00 & $1-5$ &, 76 \\
\hline A munkakör formalizáltsága & 2 & 3,10 & 1,00 & $1-5$ &, 73 \\
\hline A piackutatóval való együttmúködés mértéke & 4 & 3,50 & 1,30 & $1-5$ &, 89 \\
\hline
\end{tabular}


elemzés (eredményeink nem mutattak ki korrelációt a válaszadási reakcióidô és a kulcs- és leíró változók között) és válaszadás elutasításának okai (amelyek szintén nem leíró, illetve kulcsváltozó- specifikusak) alapján azt gondoljuk, hogy a nem válaszolásból nem okoz mintánkban szisztematikus hibát.

\section{Adatbevitel, adattisztítás, elemzés}

A modellt lineáris regresszióelemzés segítségével készítettük el. Az adatbázis kódolásához szakosított szolgáltatót vontunk be. A visszaellenốrzés során minden tizedik (10\%) kérdőívet újra egyeztettünk az adatbázisban szereplő adatokkal, amely nem tárt fel szisztematikus hibát. A modellben szereplő konstrukciókat megbízhatóság szempontjából a nemzetközi marketingkutatásokban alkalmazott, Gerbing és Anderson (1988) által leírt módszer alapján teszteltük (egydimenziójúság vizsgálata ${ }^{13}$, Cronbach-Alpha mérốszám kalkulálása, megerősító faktorelemzés ${ }^{14}$, diszkriminancia-érvényesség ${ }^{15}$ vizsgálata). A regressziós egyenletek felállítása előtt Mason és Perreault (1991) útmutatásai ${ }^{16}$ alapján kizártuk a multikollinearitás kockázatát. Kutatásunkban az SPSS 9.0 statisztikai szoftverrel dolgoztunk.

\section{Megbizhatóság és érvényesség kérdése}

A kutatás megbízhatósága és a kutatás különbözőségi (vagy diszkriminancia) érvényessége matematikai-statisztikai módszerekkel ellenőrizhetô. A skála elméleti érvényességéne $k^{17}$ becsléséhez azonban további tesztekre lenne szükség. Curchill (1979) az elméleti érvényességhez kötődően az ún. többjellemzős, többmódszeres (multitrait-multimethod) vizsgálatokat javasolja, amelynek során ugyanazt a jelenséget eltéró módon és eltérô elméleti konstrukciók segítségével különböző idốben is vizsgálják. A kutatás eredményeinek ilyen jellegú, más Magyarországon készült kutatásokkal való összevetésére nincs lehetőségünk, azonban az elméleti érvényesség vizsgálatát szolgálná egy olyan esetleges későbbi kutatás, amely során összevethető́k lesznek az eltérố idóben és alanyokkal végzett eredmények.

A kutatás elméleti érvényességére vonatkozóan jelen esetben a kutatást megelőző kvalitatív interjúsorozat és a skálafejlesztés eredményei alapján lehet következtetni. A mélyinterjú-sorozat kvázi lehetőséget biztosított arra, hogy kutatásunktól eltérô módszerrel vizsgáljuk a piackutatásból származó információk hasznosulásának jelenségét, a skálafejlesztés során pedig mód nyílt arra, hogy ha alanyaink nem ugyanazt értették egy kérdés alatt, illetve ha egy konstrukcióval kapcsolatosan egyéb szempontok is felmerültek, akkor azt a kérdőív módosításával érvényre juttassuk. Az elméleti érvényességhez járul hozzá az is, hogy a hipotézisek, illetve az összefüggések mozgatórugóival kapcsolatos feltételezések megfogalmazása során a témakör nemzetközi szakirodalmára, vagyis olyan kutatásokra támaszkodtunk, amelyek - jóllehet egy a magyar üzleti közegtôl eltérô környezetben, és ez a közvetlen összevethetőséget megnehezíti - lehetôséget adott más mérésekkel való külső összehasonlításra.

Szintén az érvényesség javítása irányába hatott, hogy a felmérés során az ún. „,ritical incident” módszert alkalmaztuk. Válaszadóinkat nem arra kértük, hogy értékeljék, általában hogyan hasznosulnak a piackutatások, hanem arra kértük óket, egy meghatározott - mégpedig a legutóbbi - kutatásra vonatkozóan adjanak választ.

\section{Összegzés}

Magyarországon a vállalatok megközelítóleg 15 százaléka vesz rendszeresen igénybe piackutatási szolgáltatásokat. Ezek közé a cégek közé jellemzően a külföldi tulajdonban lévő nagyvállalatok tartoznak, amelyek piacvezető vagy piackihívó pozícióban vannak, és a fogyasztói piacokon tevékenykednek. A magyarországi nagyvállalatok által megrendelt piackutatási tanulmányok általában hatékony döntésmegerősítő eszköznek bizonyulnak. Az esetek megközelítőleg kétharmadában jelentősen segítik a marketingvezetôt a döntéssel kapcsolatos bizonytalanságok leküzdésében; az esetek egyharmadában pedig kifejezetten a piackutatások hatására hoznak meg döntéseket a szakemberek. Az elkészült piackutatások kb. egytizedét nem használják a marketingvezetôk. Jóllehet a legtöbb megkérdezett szakember vallja, hogy a piackutatásokból lehetne tanulni is, csupán a megkérdezettek kevesebb mint egynegyede látja úgy, hogy a legutóbbi piackutatás segítségével új lehetôségek tárultak fel, vagy változott a piac természetéról alkotott képük.

A marketingvezetô és piackutató közötti bizalom szükséges, de nem elégséges feltétele annak, hogy az elkészült piackutatás valóban hasznos eszköze legyen a marketingmenedzsment-munkának. A piackutató és a marketingvezető között a bizalom kialakításában a közös munkának van a legnagyobb szerepe. A bizalom azért fontos eleme a piackutatástól a marketingtudáshoz vezető értékláncnak, mert a bizalom mértéke határozza meg leginkább, hogyan vélekedik a döntéshozó az elkészült piackutatás minőségéról. A bizalom méréseink szerint lényegesebb a piackutatás minőségének megítélésében, mint maga a piackutatás - általunk vizsgált - sajátosságai.

A piackutatás minőségéról kialakított vezetői kép játssza a legfontosabb szerepet abban, hogy a marketingvezetố támaszkodik-e a tanulmány ténymegálla- 
pításaira munkája során. A döntéshozatalba nagyobb mértékben épülnek be azok a piackutatások, amelyeket olyan vállalatok rendelnek meg, ahol a munkaköröket formális, írásban is rögzített rutinok kötik. A marketingvezetốk fóleg akkor tanulnak az elkészült piackutatásokból, ha a tanulmány ténymegállapításait konkrét problémák megoldása, döntések meghozatala során alaposan is megismerték, vagyis paradox módon az általános piacleíró tanulmányokból kisebb valószínúséggel tanulnak, vonnak le absztrakt ismereteket a vezetốk, mint a közvetlenül, a problémák megoldása során felhasznált eredményekból.

\section{A kutatás lehetséges jövớbeni folytatási irányai}

A kutatás több irányban is folytatható.

A rendelkezésre álló adatbázis módot ad arra, hogy modellünk jóságát, illetve a regressziós egyenletek illeszkedését részmintákon is teszteljük. Wierenga és Van Bruggen (1997) - a marketingmenedzsment-tevékenységet támogató informatikai eszközöket vizsgálva - vetette fel, hogy feltételezhetô, hogy a jelenségre a különbözó ágazatokban eltérő módon hatnak a magyarázó változók. Adatbázisunk segítségével - bizonyos statisztikai feltételek teljesülése esetén - vizsgálhatjuk, hogy például a telekommunikációs piacon tevékenykedô vállalatok esetében ugyanazok a változók másként hatnak-e, mint a nagykereskedelem játékosai körében, vagy különbségeket tárhatunk fel a fogyasztói (B2C) és ipari piacokon (B2B) jelen lévô vállalatok piackutatási információ-felhasználása során.

Kutatásunknak jelentôs külsô érvényességet biztosít az a tény, hogy a négymilliárd forintnál nagyobb árbevétellel rendelkezô vállalatokat teljeskörúen megkérdeztük, és 26 százalékos válaszadási arányt értünk el. Érdekes lehet - egy esetleges újabb kutatás keretein belül - a jelenséget egy, a magyarországi vállalati kört teljes egészében reprezentáló mintán is vizsgálni.

A piackutatások hasznosulásáról kutatásunkban kizárólag a felhasználói oldalt kérdeztük meg. Egy esetleges további kutatás lehetőséget teremthet arra, hogy a kutatások készítóit, a külsố piackutatókat is megkérdezzük. Ez kétféleképp is megvalósulhat. Egyrészt utólagosan készíthető egy olyan adatbázis, ahol a kérdőívünkben találhatókhoz hasonló kérdéseket teszünk fel piackutatóknak (függetlenül attól, hogy az eredeti adatbázisban szereplő marketingvezetôkkel dolgoztak-e együtt, vagy sem) - ezt a metodológiát követte Deshpandé és Zaltman (1984), amikor azt vizsgálta, hogy mennyiben él eltérő „mentális modell” a piackutatások vállalati hasznosulásáról a marketingvezetóben és a piackutatóban. Ennél azonban akkurátusabb eredményt hozhat egy diád-jellegú felmérés, vagyis egy olyan kutatás, amelyben az egy kutatáson belül együttmúködố marketingvezetôt és piackutatót kérdeznénk meg, de akár triád-jellegú felmérés is készíthetô, amelybe a piackutatás elkészítésében esetlegesen részt vevố belsố piackutatót is bevonnánk.

A témakör kutatásaiban kizárólag külső piackutatók által készített tanulmányok hasznosulását vizsgálták. Jóllehet értékét és volumenét tekintve kisebb jelentőségú, de mégiscsak érdekes kérdés lehet, hogy a vállalat belsố eróforrásaira támaszkodva elóállított piackutatások hasznosulásának mechanizmusa eltér-e, és ha igen, mennyiben a külső kutatások felhasználásától.

\section{Lábjegyzet}

${ }^{1}$ T030028 számú, „A marketingorientáció elméleti és gyakorlati megalapozása a magyarországi marketinghelyzet alapján” c. OTKA-kutatás.

${ }^{2}$ Az adatbázis ágazati megoszlásban reprezentálja a vállalatok besorolását; vállalati méret szerint azonban az alapsokaságnál magasabb arányban jelennek meg nagyobb vállalatok.

${ }^{3}$ Az $\mathrm{R}$ négyzet a modell illeszkedésének mérōszáma. Értéke 0-1 között lehet, minél magasabb az értéke, a modell annál jobbnak tekinthetô. Az $\mathrm{R}$ négyzet értéke megmutatja, hogy a független változók a függó változó teljes varianciájának mekkora részét magyarázzák meg. Malhotra (2001) 726, 732. oldal.

${ }^{4}$ John és Martin (1984) a formalizáltságot úgy operacionalizálják, hogy milyen mértékben jellemzóek specifikus szabályokat és folyamatokat követniük a marketing-szakembereknek a marketing terv elkészítése során.

${ }^{5}$ Mohr - Fisher et al. (1996) kutatásukban nem tesznek különbséget a döntéshozatalhoz és piaci tanuláshoz kapcsolódó információ felhasználás között.

${ }^{6}$ Low és Mohr (2001) az információ-felhasználás jelenségét a marketingkommunikációs tevékenység értékeléséhez kapcsolódóan vizsgálta.

${ }^{7}$ Az ábrán szereplő ,intelligencia” az angol „market intelligence” kifejezést jelöli, melynek egyelőre nincs széles körben elfogadott és konszenzuson alapuló magyar megfelelője. A kifejezés a piaci szórványinformációk gyújitését, rendszerezését és összekapcsolását jelenti. Bauer és Berács (1998) marketing-felderítésnek (473. oldal) fordítja, míg Kotler (1991) magyar nyelvú kiadásában a marketing-megfigyelés (106. oldal) kifejezéssel találkozhatunk. Az üzleti gyakorlatban a szó tükörfordítása (intelligencia) túnik létjogosultságot nyerni (pl. üzleti intelligencia megoldások).

${ }^{8}$ T037857 számú, „Marketingmenedzsment-tevékenységet támogató információrendszerek és a piaci tudás felhasználása Magyarországon" c. OTKA-kutatás

${ }^{9}$ A megbízhatóság azt fejezi ki, hogy egy skála milyen mértékben ad konzisztens eredményeket ismételt mérések esetén. Malhotra (2001), 347. oldal.

${ }^{10}$ Cronbach Alpha definíciója!, melynek értéke 0,6 fölött mondható elfogadhatónak.

${ }^{11}$ A nagyvállalatokat éves négymilliárd forintot meghaladó árbevétellel operacionalizáltuk.

12 A témához kapcsolódó amerikai kutatásokban (Zinkhan, Joachimsthaler et al., 1987; Moorman, Zaltman et al., 1992; 
Deshpandé és Zaltman, 1982/a; Deshpandé, 1982/b; Moorman, 1995; Moorman, Deshpandé et al., 1993) a minta kialakítása során kizárólag a legtöbbet reklámozó vállalatokat vizsgálták, azt feltételezve, hogy a sokat reklámozó vállalatok költenek egyben legtöbbet piackutatásra is. A kutatók ugyanakkor a mintakialakítás rutinjának e módját a tanulmány korlátjaként tüntették fel, hiszen így nem tudtak képet alkotni a kevesebbet kutató vállalatok információfelhasználási hatásmechanizmusáról. Azzal, hogy kutatásunkban teljeskörúen vizsgáltuk a magyarországi nagyvállalatokat, sikerült átlépnünk ezt a kutatási korlátot. Felmérésünkben csupán azokat a vállalatokat zártuk ki, amelyek az elmúlt öt évben egyáltalán nem készítettek piackutatást. Eredményeink - például, hogy az önálló belsó piackutatói munkakörrel rendelkező vállalatoknál bizonyos hatásmechanizmusok máshogy érvényesülnek - arra engednek következtetni, hogy kizárólag a sokat kutató vállalatok vizsgálata valóban az eredmények általánosíthatósága ellen hat.

${ }^{13}$ Az egydimenziójúság értékelése során meg kell vizsgálni, hogy a skálákban szereplő állítások (tételek) mindegyike az adott latens konstrukcióra vonatkozik-e. Ehhez vizsgálni kell a skálákban szereplő egyes elemek többi elemmel mért korrelációs (itemto-total) együtthatóját A skála azon tételeit törölni kell, ahol a korrelációs együttható értéke nem haladja meg a 0,3 értéket. Ezt követôen faktorelemzéssel ellenórizhetô, hogy az elméletileg a konstrukcióhoz tartozó tételek valóban egy faktorba tartoznak-e. Amennyiben egy faktorba kerülnek, a skála egydimenziójú, így alkalmazhatjuk a megbízhatóság Cronbach Alpha mérôszámát.

${ }^{14}$ A skálák egydimenziójúságának szigorúbb mérési módszere az ún. megerôsítő faktorelemzés (confirmatory factor analisys), amikor valamennyi állítás együttes bevonásával végzünk faktorelemzést. Ilyenkor azt vizsgáljuk, hogy egyrészt a változó valóban ahhoz, és nem másik faktorhoz (latens konstrukcióhoz) tartozik-e, amelyhez korábban kapcsoltuk, illetve vizsgáljuk, hogy a változó milyen erôsen kapcsolódik az adott faktorhoz. Amennyiben a változó nem a feltételezések szerinti latens konstrukcióhoz, vagy nem elég erôsen (<0,5 faktorsúly) kapcsolódik, az állítást törölni kell, és újra kalkulálni a skála megbízhatóságát.

${ }^{15}$ A diszkriminancia-érvényesség - vagyis annak vizsgálata, hogy két egydimenziójú faktor (latens konstrukció) valóban különbözó tartalommal bír - vizsgálatához a faktorok korrelációját kell megvizsgálni. Amennyiben a korrelációk 1,00-nél szignifikánsan alacsonyabbak (Bagozzi - Phillips, 1982), teljesül a diszkriminancia- érvényesség kritériuma. Ellenkezó esetben újabb faktorelemzést célszerú végezni a dimenziókhoz tartozó faktorokkal (second order factor analysis / másodfokú faktorskálák). Amennyiben a második faktorelemzés során csupán egy faktort kapunk - és a faktorelemzés a jellemző statisztikai mutatószámok alapján adekvát eljárás - elmondható, hogy egyetlen konstrukcióról van szó, és az elemeket össze lehet vonni.

${ }^{16}$ Mason és Perreault (1991) azt javasolja, hogy a regressziós egyenletben szereplô valamennyi változó függó változóként való behelyettesítése esetére számoljuk ki az egyenlet $\mathrm{R}$ négyzet értékét. Amennyiben a többi egyenlet $\mathrm{R}$ négyzet értéke kisebb, mint az eredeti (modellben meghatározott független változók és függô változó kapcsolatrendszerén alapuló) regressziós egyenlet $\mathrm{R}$ négyzet értéke, a multikollinearitás nem jelent problémát.

${ }^{17}$ Elméleti érvényesség (Nomological validity) azt fejezi ki, hogy a skála mennyire korrelál elméletileg előre jelzett módon más, de összefüggő fogalmak méréseivel (Malhotra 2001), 350. oldal.

\section{Felhasznált irodalom}

Armstrong, J.S. - Overton, T.S. (1977): Estimating Nonresponse Bias in Mail Surveys. Journal of Marketing Research, 14 (August), 396-402. o.

Bagozzi, R.P. - Phillips, L.W. (1982): Representing and Testing Organisational Theories: A Holistic Construal. Adminsitrative Science Quarterly, 27 (September), 459-489. o.

Barabba, V.P. - Zaltman, G. (1991): Hearing the Voice of the Market: Competitive Advantage Through Creative Use of Market Information. Boston, Harvard University Press

Bauer, A. - Berács, J. (1998): Marketing, Budapest, Aula Kiadó Berács, J. - Keszey, T. - Sajtos, L. (2001): A magyarországi vállalatok marketing megközelítése, stratégiája és teljesítménye 2000-ben, T030028 témaszámú, „A marketingorientáció elméleti megalapozása a magyarországi marketinghelyzet alapján" címú OTKA kutatási program (1999-2001), III. tanulmánykötet, Budapest, BKÁE Marketing Tanszék, 1-170. o.

Beyer, J.M. - Trice, H.M. (1982): The Utilization Process: A Conceptual Framework and Synthesis of Empirical Findings. Administrative Science Quarterly, 27, 591-622. o.

Caplan, N. - Morisson, A. et al. (1975): The Use of Social Science in Public Policy Decisions at the National Level. Michigan, Institute for Social Research

Curchill, G. A. (1979): A Paradigm for Developing Better Measures of Marketing Constructs. Journal of Marketing Research, 16 (February), 64-73. o.

Daft, R.L. - Lengel, R.H. (1986): Organizational Information Requirements, Media Richness and Structural Design. Management Science, 32 (May), 554-571.

Dalebout, A. (1993): Management Support for the Product Manager. Rotterdam School of Management, Erasmus University

Deshpandé, R. (1982): The Organizational Context of Market Research Use. Journal of Marketing, 46(Fall), 91-101. o.

Deshpandé, R. - Zaltman, G. (1982): Factors Affecting the Use of Market Research Information: A Path Analysis. Journal of Marketing Research, 19 (February), 14-31. o.

Deshpandé, R. - Zaltman, G. (1984): A Comparsion of Factors Affecting Researcher and Manager Perceptions of Market Research Use. Journal of Marketing Research, 21 (February), 32-38. o.

Deshpandé, R. - Zaltman, G. (1987): A Comparsion of Factors Affecting Use of Marketing Information in Consumer and Industrial Firms. Journal of Marketing Research, 24 (February), 117-127. o.

Earl, M. J. - Edwards, B. et al. (1997): Configuring the IS Function in Complex Organizations. Managing IT as a Strategic Resource. L. Willcocks, D. Feeny, G. Isley and eds. London, McGraw-Hill

Galbraith, J.R. (1973): Designing Complex Organisations. Reading, MA, Addison-Wesley

Gerbing, D. - Anderson, J. (1988): An Updated Paradigm for Scale Development Incorporating Unidimensionality 
and its Assesment. Journal of Marketing Research, 25 (May), 186-192. o.

Griffin, A. - Hauser, J.R. (1992): Patterns of Communication Among Marketing, Engineering and Manufacturing - A Comparison of Two New Product Teams. Management Science, 38 (3), 360-374. o.

Haeckel, S.H. (1987): Presentation to the Information Planning Steering Group. Cambridge, MA, Marketing Science Institute, October

Hart, S. - Diamantopoulos, A. (1993): Linking Market Orientation and Company Performance: Preliminary Work on Kohli and Jaworski's Framework. Journal of Strategic Marketing, 93-122. o.

Hooley, G. - Cox, T. et al. (2000): Market Orientation in the Transition Economies of Central Europe: Tests of the Narver and Slater Market Orientation Scales. Journal of Business Research, 50, 273-285. o.

Jaworski, B.J. - Kohli, A.K. (1993): Market Orientation: Antecedents and Consequences. Journal of Marketing, 57 (July), 53-70. o.

John, G. - Martin, J. (1984): Effects of Organizational Structure of Marketing Planning on Credibility and Utilization of Plan Output. Journal of Marketing Research, 21 (May), 170-183. o.

Keszey, T. (2003): Hogyan hasznosulnak a piackutatásból származó információk a vállalatok marketingmenedzsment gyakorlatában? Vezetéstudomány, 34 (11): 32-46. o.

Kohli, A.K. - Jaworski, B.J. (1990): Market Orientation: The Construct, Research Propositions and Managerial Implications. Journal of Marketing, 54 (2), 1-18. o.

Lee, H. - Acito, F. et al. (1987): Evaluation and Use of Marketing Research by Decision Makers: A Behavioral Simulation. Journal of Marketing Research, 24 (May), 187-196. o.

Low, G.S. - Mohr, J.J. (2001): Factors Affecting the Use of Information in the Evaluation of Marketing Communications Productivity. Journal of the Academy of Marketing Science, 29 (Winter), 70-88. o.

Maltz, E. - Kohli, A.K. (1996): Market Intelligence Dissemination Across Functional Boundaries. Journal of Market Research, 33 (February), 47-61. o.

Maltz, E. - Kohli, A.K. (2001): Market Intelligence Dissemination Across Functional Boundaries. Using Market Knowledge. R. Deshpandé. London, Sage Publications: 273-314. o.

Mason, C. H. - Perreault, W.D.J. (1991): Collinearity, Power and Interpretation of Multiple Regression Analysis. Journal of Marketing Research, 28 (August), 268-280. o.

Menon, A. - Varadarajan, R. (1992): A Model of Marketing Knowledge Use Within Firms. Journal of Marketing, 56 (4), 53-72. o.

Menon, A. - Wilcox, J.B. (2001): USER: A Scale to Measure Use of Market Research. Using Market Knowledge. R. Deshpandé. London, Sage Publications: 243-272. o.

Moenaert, R.K. - Souder, W. (1996): Context and Antecedents of Information Utility at the R\&D / Marketing Interface. Management Science, 42 (11), 1592-1610. o.
Mohr, J. - Fisher, R.J. et al. (1996): Collaborative Communication in Interfirm Relationships: Moderating Effects of Integration and Control. Journal of Marketing, 60 (3), 103-115. o.

Moorman, C. (1995): Organizational Market Information Processes: Cultural Antecedents and New Product Outcomes. Journal of Marketing Research, 32 (August), 318-335. o.

Moorman, C. - Zaltman, G. et al. (1992): Relationships Between Providers and Users of Market Research: The Dynamics of Trust Within and Between Organizations. Journal of Marketing Research, 24 (August), 314-328. o.

Narver, J.C. - Slater, S.F. (1990): The Effect of Marketing Orientation on Business Profitability. Journal of Marketing, 58, 20-38. o.

Nonaka, I. - Takeuchi, H. (1995): The Knowledge-Creating Company., Oxford University Press

O'Reilly, C. A. (1982): Variation is Decision Makrs' Use of Information Sources: The Impact of Quality: The Impact of Quality and Accessibility of Information. Academy of Management Journal, 25 (4), 173-194. o.

Osterloh, M. - Frey, B.S. (2000): Motivation, Knowledge Transfer, and Organizational Forms. Organization Science, 11(5, September-October), 538-550. o.

Rindfleisch, A. - Moorman, C. (2001): The Acquisition and Utilization of Information in New Product Alliances: A Strength-of-Ties Perspective. Journal of Marketing, 65 (April), 1-18. o.

Slater, S.F. - Narver, J.C. (1995): Market Orientation and the Learning Organization. Journal of Marketing, 59 (July), 63-74. o.

Törốcsik, M. (1996): Ipari marketing. Bp., Nemz. Tankönyvk.

Tushman, M.L. -Nadler, D.A. (1978): Information-Processing as an Integrating Concept in Organisational Design. Academy of Management Review, 3, 613-624. o.

Van den Bulte, C.-Moenaert, R.K. (1998): The effects of R\&D team co-location on communication patterns among $\mathrm{R} \& \mathrm{D}$, marketing, and manufacturing. Management Science, 44 (11), S1-S18. o.

Wierenga, B. - Van Bruggen, G.H. (1997): The Integration of Marketing Problem-Solving Modes and Marketing Management Support Systems. Journal of Marketing, vol. 61 (July), 21-37. o.

Zaltman, G. - Deshpandé, R. (2000): The Use of Market Research - An Exploratory Study of Manager and Researcher Perspectives. Using Market Knowledge. R. Deshpandé. Thousand Oaks, Sage Publications, Inc.: 31-81. o.

Zaltman, G. - Duncan, R. et al. (1973): Innovations and Organizations. New York, John Wiley\&Sons

Zaltman, G. - Moorman, C. (1988): The Importance of Personal Trust in the Use of Research. Journal of Advertising Research, 28 (3), 16-24. o.

Cikk beérkezett: 2006. 9. hó

Lektori vélemény alapján átdolgozva: 2007. 3. hó 